DOI: $10.17707 /$ AgricultForest.65.1.20

\author{
Volodymyr HUDZENKO, Oleksandr DEMYDOV, \\ Hanna VOLOSHCHUK, Mykola SARDAK, Vitalii ISHCHENKO ${ }^{1}$
}

\title{
GENOTYPE BY ENVIRONMENT INTERACTION AND YIELD STABILITY OF BARLEY BREEDING LINES IN MULTI-ENVIRONMENT TRIALS
}

\begin{abstract}
SUMMARY
In modern conditions it is necessary to create varieties of spring barley with combination of high grain yield and stability. For this purpose, multienvironment trials of nine advanced breeding lines and the standard variety Vzirets were carried out in three different ecological zones in Ukraine: Central Forest-Steppe, Polissia and Northern Steppe. High yield variability of spring barley breeding lines has been established. The ANOVA revealed reliable contributions from all three source of the variation: genotype, environment and genotype-environment interaction. The part of influence for environment was the highest $-90.42 \%$. A set of statistical indices (regression coefficient $\left(b_{i}\right)$, deviation mean squares $\left(\mathrm{S}^{2} \mathrm{~d}_{\mathrm{i}}\right)$, variety superiority measure $\left(\mathrm{P}_{\mathrm{i}}\right)$, nonparametric stability indices $\left(\mathrm{S}_{\mathrm{i}}{ }^{(1)}\right.$ and $\left.\mathrm{S}_{\mathrm{i}}{ }^{(2)}\right)$, homeostaticity $\left(\operatorname{Hom}_{\mathrm{i}}\right)$, breeding value $\left(\mathrm{Sc}_{\mathrm{i}}\right)$ ) and GGE biplot were used to interpret the multi-environment trial data. The applied statistical indices in different ways characterized the investigated barley breeding lines. Some indices estimated the stability only, without considering yield level $\left(\mathrm{S}^{2} \mathrm{~d}_{\mathrm{i}}, \mathrm{S}_{\mathrm{i}}{ }^{(2)}\right)$. Other indices were related with the mean yield $\left(\mathrm{P}_{\mathrm{i}}\right)$, with the maximum $\left(b_{i}\right)$ or minimum $\left(\mathrm{S}_{\mathrm{i}}{ }^{(1)}, \mathrm{Hom}_{\mathrm{i}}, \mathrm{Sc}_{\mathrm{i}}\right)$ its value. The combination of statistical indices and graphic model was effective for comprehensive evaluation of the genotype-environment data from multi-environment trials. This approach allows identify the best of the best breeding lines at the final stage of breeding work. The breeding lines Deficiens 5005, Nutans 4855, Nutans 4941 and Nutans 4890 have been submitted to the State Strain Testing of Ukraine as new varieties MIP Visnyk, MIP Ekspert, MIP Myroslav, MIP Vdiachnyi, respectively.

yield

Key words: Hordeum vulgare L., GGE biplot, stability, statistical indices,

\section{INTRODUCTION}

Plant breeding has been making significant contribution to improve productivity of the main crops. Significant increase barley (Hordeum vulgare L.)

\footnotetext{
${ }^{1}$ Volodymyr Hudzenko (corresponding author: barley0482@gmail.com), Oleksandr Demydov, Hanna Voloschuk, The V.M. Remeslo Myronivka Institute of Wheat of the National Academy of Agrarian Sciences of Ukraine, Tsentralne village, Myronivka district, Kyiv region, UKRAINE; Mykola Sardak, Nosivka Plant Breeding and Experimental Station of the V. M. Remeslo MIW of NAAS, Doslidne village, Nosivka district, Chernihiv region, UKRAINE; Vitalii Ischenko, Institute of Agriculture of Steppe of NAAS, Sozonivka village, Kirovohrad district, Kirovohrad region, UKRAINE

Notes: The authors declare that they have no conflicts of interest. Authorship Form signed online.
} 
production as a result of breeding improvement was noted in Austria (Grausgruber et al., 2002), Norway (Lillemo et al., 2009), Czech Republic (Psota et al., 2009), Germany (Laidig et al., 2017). However, in conditions of climate change, there are needed not only high-yielding, but also environmentally stable varieties (Macholdt, Honermeier, 2016). One of the major problems in plant breeding for improve and stabilize yield is genotype-environment interaction (Hill, 1975). The genotype-environment interaction is part of the phenotypic variation that occurs as a result of non-compliance between genetics and environmental effects. Environments differ in the amount and quality of inputs that they convey to plants: water, nutrients, radiation, etc. This leads to the fact that the selection of genotypes under certain conditions may not provide the advantage of these genotypes in other conditions (Malosetti et al., 2013). According to mentioned, at the final stage of selection, breeding lines should be comprehensively evaluated. To assess the genotype-by-environment interaction are effective multi-environment trials (Sabaghnia et al., 2013). To interpret the experimental data of multi-environment trials, it is necessary to use the most appropriate statistical models (Eeuwijk et al., 2016). To evaluate barley yield stability a number of parametric and non-parametric stability indices have been used (Dimova et al., 2012; Verma, 2017). However, comprehensive genotypeenvironment data analysis must cover not only genotype evaluation, but two other important aspects: mega-environment analysis and test-environment evaluation (Yan and Tinker, 2006). For this purpose the more and more researchers have used GGE (genotype plus genotype by environment interaction) biplot (Vaezi et al., 2017; Kiliç et al., 2018; Khanzadeh et al. 2018; Solonechnyi et al., 2018). The advantages of GGE biplot are the ability to visualize the distribution of genotypes and environments in coordinates of the principal components, as well as to combine a genotype and genotype-environment interaction in mega-environment analysis (Yan, Tinker, 2006; Yan et al., 2007).

The present study aimed to evaluate of the genotype by environment interaction and identify spring barley breeding lines that combine yield performance and stability in the multi-environment trials.

\section{MATERIALS AND METHODS}

Nine spring barley advanced breeding lines and the standard variety Vzirets were tested. The breeding lines have been selected by complex of traits in competitive strain tasting at The V. M. Remeslo Myronivka Institute of Wheat of NAAS in 2015. In 2016-2018, the study was carried out through three environmental zones. 1) The V. M. Remeslo Myronivka Institute of Wheat of NAAS (Central Forest-Steppe, Latitude $-49^{\circ} 64^{\prime}$, Longitude $-31^{\circ} 08^{\prime}$, Altitude $153 \mathrm{~m}$ ). Soils are deep, little humus, slightly leached black soil. Humus content $3.8 \%$, alkaline hydrolyzed nitrogen $-5.9 \mathrm{mg} / 100 \mathrm{~g}, \mathrm{P}_{2} \mathrm{O}_{5}-22.1 \mathrm{mg} / 100 \mathrm{~g}, \mathrm{~K}_{2} \mathrm{O}$ - $9.6 \mathrm{mg} / 100 \mathrm{~g}, \mathrm{pH}=5.8$. 2) Nosivka Plant Breeding and Experimental Station of the V. M. Remeslo MIW of NAAS (Polissia, Latitude - 50 ${ }^{\circ} 3^{\prime}$, Longitude $31^{\circ} 69^{\prime}$, Altitude $-126 \mathrm{~m}$ ). 
Soils are modal, little humus, leached black soil. Humus content $2.6 \%$, nitrogen - $8.5 \mathrm{mg} / 100 \mathrm{~g}, \mathrm{P}_{2} \mathrm{O}_{5}-12.2 \mathrm{mg} / 100 \mathrm{~g}, \mathrm{~K}_{2} \mathrm{O}-7.5 \mathrm{mg} / 100 \mathrm{~g}, \mathrm{pH}=4.6$. 3) Institute of Agriculture of Steppe of NAAS (Nothern Steppe, Latitude $48^{\circ} 56^{\prime}$, Longitude $-32^{\circ} 32^{\prime}$, Altitude $-171 \mathrm{~m}$ ). Soils are deep, middle humus, clay loamy black soil. Humus content $4.6 \%$, nitrogen $-12.0 \mathrm{mg} / 100 \mathrm{~g}, \mathrm{P}_{2} \mathrm{O}_{5}-$ $11.6 \mathrm{mg} / 100 \mathrm{~g}, \mathrm{~K}_{2} \mathrm{O}-11.8 \mathrm{mg} / 100 \mathrm{~g}, \mathrm{pH}=5.4$. Meteorological conditions of research significantly differed between ecological zones and years (Table 1).

The trial was laid out with complete randomized blocks in a three replications in each ecological zone.

Table 1. Meteorological conditions during the spring barley growing season

\begin{tabular}{|c|c|c|c|c|c|c|c|c|c|c|c|}
\hline \multirow{2}{*}{ Year } & \multirow{2}{*}{ Code } & \multicolumn{1}{c|}{ Monthly air temperature ${ }^{\circ} \mathrm{C}$} & \multicolumn{3}{c|}{ Monthly precipitation mm } \\
\cline { 2 - 10 } & & April & May & June & July & April & May & June & July \\
\hline \multicolumn{1}{|c|}{ The V.M. Remeslo Myronivka Institute of Wheat of NAAS } \\
\hline 2015 & M15 & 9.3 & 16.3 & 19.4 & 21.5 & 34.0 & 55.0 & 101.0 & 99.0 \\
\hline 2016 & M16 & 12.4 & 15.2 & 20.1 & 22.2 & 55.4 & 91.7 & 68.6 & 19.1 \\
\hline 2017 & M17 & 10.4 & 15.4 & 20.6 & 21.0 & 42.7 & 23.6 & 20.1 & 101.8 \\
\hline 2018 & M18 & 13.3 & 18.4 & 20.2 & 20.9 & 21.1 & 33.3 & 95.0 & 74.8 \\
\hline Long-term & 8.8 & 15.0 & 18.0 & 19.7 & 42.1 & 51.2 & 85.2 & 86.5 \\
\hline Nosivka Plant Breeding and Experimental Station of the V. M. Remeslo MIW \\
\multicolumn{8}{|c|}{ of NAAS } \\
\hline 2016 & N16 & 11.7 & 15.3 & 20.0 & 21.8 & 58.4 & 122.9 & 36.5 & 51.3 \\
\hline 2017 & N17 & 9.5 & 13.9 & 18.6 & 19.1 & 35.4 & 44.3 & 33.0 & 109.3 \\
\hline 2018 & N18 & 11.4 & 17.5 & 19.2 & 20.3 & 2.0 & 31.0 & 64.0 & 81.0 \\
\hline Long-term & 7.9 & 15.0 & 18.4 & 20.2 & 35.6 & 45.1 & 64.5 & 73.0 \\
\hline \multicolumn{10}{|c|}{ Institute of Agriculture of Steppe of NAAS } \\
\hline 2016 & K16 & 13.9 & 17.3 & 22.2 & 24.3 & 52.3 & 153.2 & 107.5 & 15.5 \\
\hline 2017 & K17 & 10.9 & 17.6 & 23.1 & 23.2 & 23.5 & 10.7 & 22.2 & 66.0 \\
\hline 2018 & K18 & 15.0 & 20.8 & 22.9 & 23.7 & 10.0 & 25.5 & 29.2 & 141.0 \\
\hline Long-term & 8.9 & 15.3 & 18.6 & 20.0 & 36.0 & 45.0 & 66.0 & 72.0 \\
\hline
\end{tabular}

The widespread statistical indices were determined: regression coefficient $b_{i}$ and deviation mean squares $S^{2} d_{i}$ (Eberhart S.A., Russel W.A., 1966), variety superiority measure $P_{i}$ (Lin, Binns, 1988), nonparametric stability indices $S_{i}^{(1)}$ and $\mathrm{S}_{\mathrm{i}}{ }^{(2)}$ (Huehn, 1990). Also, there were determined the two less common indices: homeostaticity index $\left(\mathrm{Hom}_{\mathrm{i}}\right)$ and breeding value $\left(\mathrm{Sc}_{\mathrm{i}}\right)$ (Khangil'din, Litvinenko, 1981): $\operatorname{Hom}_{i}=x^{2} / \sigma, S c_{i}=x * x_{\text {lim }} / x_{\text {opt }}$, where $x$ is the mean yield of genotype, $\sigma$ is the standard deviation, $x_{\lim }$ is the minimum yield of genotype, $x_{\text {opt }}$ is the maximum yield of genotype. AMMI and GGE biplot analysis was performed using non-commercial software GEA-R. Software review is provided in the publication (Frutos et al., 2014). 


\section{Grain yield}

\section{RESULTS AND DISCUSSION}

The level of spring barley breeding lines yield significantly varied, depending on the ecological location and meteorological conditions of the year (Table 2). On average across environments, the breeding lines Nutans 4941, Deficiens 5005, Nutans 4855, Nutans 4983 reliably exceeded the standard variety Vzirets. The breeding lines Nutans 4890 and Pallidum 5023 exceeded the standard unreliably. The mean yield of the lines Nutans 4867, Nutans 4693, Nutans 5006 was unreliably lower than in the standard variety Vzirets.

Table 2. Grain yield of spring barley breeding lines in the multi-environment trial, $\mathrm{t} \mathrm{ha}^{-1}$

\begin{tabular}{|l|c|c|c|c|c|c|c|c|c|c|c|}
\hline \multicolumn{1}{|c|}{$\begin{array}{c}\text { Standard, } \\
\text { breeding lines }\end{array}$} & \multicolumn{9}{|c|}{ Grain yield in the environments } & \multirow{2}{*}{ Mean } \\
\hline Vzirets & 7.02 & 6.88 & 4.66 & 2.90 & 6.01 & 6.61 & 4.53 & 5.73 & 4.53 & 3.25 & 5.21 \\
\hline Nutans 4983 & 7.32 & 6.32 & 4.56 & 3.47 & 6.70 & 7.06 & 6.12 & 5.67 & 4.73 & 3.48 & 5.54 \\
\hline Nutans 4890 & 7.35 & 7.59 & 5.27 & 3.69 & 6.01 & 6.38 & 5.21 & 5.21 & 4.32 & 3.34 & 5.44 \\
\hline Deficiens 5005 & 7.63 & 7.88 & 5.20 & 3.24 & 6.73 & 6.55 & 6.55 & 5.66 & 4.20 & 2.83 & 5.65 \\
\hline Nutans 5006 & 7.67 & 5.39 & 4.56 & 2.52 & 5.20 & 7.03 & 6.30 & 4.28 & 4.22 & 2.80 & 5.00 \\
\hline Nutans 4941 & 7.74 & 7.78 & 5.42 & 3.95 & 7.07 & 7.01 & 5.65 & 5.16 & 4.56 & 3.09 & 5.74 \\
\hline Nutans 4693 & 7.12 & 6.74 & 4.75 & 2.74 & 6.28 & 6.01 & 5.35 & 4.99 & 4.26 & 3.25 & 5.15 \\
\hline Nutans 4855 & 7.57 & 7.41 & 5.37 & 3.22 & 6.80 & 7.15 & 6.19 & 5.69 & 4.12 & 2.80 & 5.63 \\
\hline Nutans 4867 & 7.34 & 6.52 & 4.92 & 2.65 & 5.65 & 6.23 & 5.72 & 4.86 & 4.36 & 3.63 & 5.19 \\
\hline Pallidum 5023 & 8.35 & 6.34 & 4.25 & 2.35 & 5.85 & 6.87 & 5.66 & 5.59 & 3.71 & 3.18 & 5.22 \\
\hline \multicolumn{1}{|c|}{ LSD $_{05}$} & 0.23 & 0.31 & 0.33 & 0.24 & 0.45 & 0.22 & 0.40 & 0.19 & 0.41 & 0.15 & 0.29 \\
\hline
\end{tabular}

Analysis of variance showed a significant advantage of the contribution of environmental conditions in the total variation - $90.42 \%$. The genotypeenvironment interaction contribution was $7.03 \%$, the genotype $-2.55 \%$ (Table $3)$.

Table 3. Analysis of variance of the grain yield in spring barley breeding lines

\begin{tabular}{|l|c|c|c|c|}
\hline \multicolumn{1}{|c|}{ Source } & $\begin{array}{c}\text { Sum of } \\
\text { squares }\end{array}$ & $\begin{array}{c}\text { Degree of } \\
\text { freedom }\end{array}$ & $\begin{array}{c}\text { Mean } \\
\text { square }\end{array}$ & $\begin{array}{c}\text { Percentage relative to } \\
\text { the sum of squares }\end{array}$ \\
\hline Genotype (G) & 630.31 & 9 & $70.03^{* *}$ & 90.42 \\
\hline Environment (E) & 17.74 & 9 & $1.97^{* *}$ & 2.55 \\
\hline Gx E & 49.00 & 81 & $0.60^{* *}$ & 7.03 \\
\hline Residuals & 6,54 & 200 & 0.03 & 0 \\
\hline
\end{tabular}

** - significant at $1 \%$ level of a probability 
Despite the low numerical values of the last two, they were reliable. Such results, in our opinion, sufficiently indicate strong variation in yield depending on the contrasting environmental conditions and conditions of the year of the research. Low numerical values of genotype variation are also due to the fact that the best breeding lines were involved in the trial. At that time, such research conditions made it possible to comprehensively evaluate the breeding lines and to select the best ones among them.

\section{Stability analysis}

Numerical values of stability are presented in Table 4. According to the regression coefficient $b_{i}$, the breeding lines Nutans 5006 (G5) and Nutans 4941 (G6) were approximated to the optimal reaction to change of environmental conditions $\left(b_{i}=1.0\right)$. The breeding line Nutans 4890 (G3) responded to the changing conditions the least of all, whereas the response of the breeding line Pallidum 5023 (G10) was the most. The breeding lines Nutans 4693 (G7), Nutans 4855 (G8), and Nutans 4867 (G9) were stable in variance $S^{2} \mathrm{~d}_{\mathrm{i}}$. According to the variety superiority measure $\mathrm{P}_{\mathrm{i}}$, the breeding lines Nutans 4941 (G6), Deficiency 5005 (G4), and Nutans 4855 (G8) should be distinguished. The lines Nutans 4890 (G3) and Nutans 4693 (G7) were stable according to non-parametric parameters $\mathrm{Si}^{(1)}$ and $\mathrm{Si}^{(2)}$, respectively. The breeding lines Nutans 4983 (G2) and Nutans 4890 (G3) were the best according to homeostaticity index $\mathrm{Hom}_{\mathrm{i}}$ and breeding value $\mathrm{Sc}_{\mathrm{i}}$.

Table 4. Characteristics of spring barley breeding lines by parametric and nonparametric stability indices

\begin{tabular}{|l|c|c|c|c|c|c|c|c|}
\hline \multirow{2}{*}{$\begin{array}{c}\text { Standard, } \\
\text { breeding lines }\end{array}$} & \multirow{2}{*}{ Code } & \multicolumn{7}{|c|}{ Stability indices } \\
\cline { 3 - 9 } & & $\mathrm{b}_{\mathrm{i}}$ & $\mathrm{S}^{2} \mathrm{~d}_{\mathrm{i}}$ & $\mathrm{P}_{\mathrm{i}}$ & $\mathrm{S}_{\mathrm{i}}{ }^{(1)}$ & $\mathrm{S}_{\mathrm{i}}{ }^{(2)}$ & $\mathrm{Hom}_{\mathrm{i}}$ & $\mathrm{Sc}_{\mathrm{i}}$ \\
\hline Vzirets & $\mathrm{G} 1$ & 0.92 & 0.20 & 0.51 & 0.47 & 7.81 & 18.53 & 2.15 \\
\hline Nutans 4983 & $\mathrm{G} 2$ & 0.90 & 0.13 & 0.24 & 0.47 & 9.44 & 21.77 & 2.63 \\
\hline Nutans 4890 & $\mathrm{G} 3$ & 0.89 & 0.16 & 0.28 & 0.38 & 6.33 & 20.71 & 2.39 \\
\hline Deficiens 5005 & $\mathrm{G} 4$ & 1.12 & 0.15 & 0.12 & 0.56 & 6.67 & 18.17 & 2.03 \\
\hline Nutans 5006 & $\mathrm{G} 5$ & 1.02 & 0.48 & 0.81 & 0.71 & 10.89 & 14.85 & 1.64 \\
\hline Nutans 4941 & $\mathrm{G} 6$ & 1.03 & 0.17 & 0.09 & 0.49 & 7.11 & 20.36 & 2.28 \\
\hline Nutans 4693 & $\mathrm{G} 7$ & 0.94 & 0.04 & 0.45 & 0.47 & 3.14 & 18.32 & 1.98 \\
\hline Nutans 4855 & $\mathrm{G} 8$ & 1.12 & 0.07 & 0.13 & 0.51 & 8.22 & 18.28 & 2.08 \\
\hline Nutans 4867 & $\mathrm{G} 9$ & 0.90 & 0.08 & 0.46 & 0.53 & 7.11 & 19.18 & 1.87 \\
\hline Pallidum 5023 & $\mathrm{G} 10$ & 1.16 & 0.21 & 0.50 & 0.64 & 8.23 & 14.86 & 1.47 \\
\hline
\end{tabular}

For a more detailed clarification of relationship between yield level and stability indices, correlation analysis was carried out (Table 5). Functional negative correlation was observed between mean yield and $\mathrm{P}_{\mathrm{i}}$. The $\mathrm{S}_{\mathrm{i}}{ }^{(2)}$ and $\mathrm{b}_{\mathrm{i}}$ not correlated with mean yield. The weak negative correlation was noted between 
mean yield and $\mathrm{S}^{2} \mathrm{~d}_{\mathrm{i}}$, mean yield and $\mathrm{S}_{\mathrm{i}}{ }^{(1)}$. The moderate positive relationship of $\mathrm{Hom}_{\mathrm{i}}$ and $\mathrm{Sc}_{\mathrm{i}}$ with mean yield was observed. Maximum yield had positively correlation with $b_{i}$ only. The relationship between minimum yield and $\mathrm{Hom}_{\mathrm{i}}$, minimum yield and $\mathrm{Sc}_{\mathrm{i}}$ was close to the functional. Between the individual indices, it should be noted the functional relationship between $\operatorname{Hom}_{i}$ and $\mathrm{Sc}_{\mathrm{i}}$. A strong negative relation was noted between $\mathrm{S}_{\mathrm{i}}{ }^{(1)}$ and $\mathrm{Hom}_{\mathrm{i}}, \mathrm{S}_{\mathrm{i}}{ }^{(1)}$ and $\mathrm{Sc}_{\mathrm{i}}$. Mean yield more correlated with the minimum yield level than with the maximum one.

Table 5. Correlation between yield and stability indices

\begin{tabular}{|l|c|c|c|c|c|c|c|c|c|}
\hline $\begin{array}{l}\text { Yield, } \\
\text { indices }\end{array}$ & Mean & Max & Min & $\mathrm{b}_{\mathrm{i}}$ & $\mathrm{S}^{2} \mathrm{~d}_{\mathrm{i}}$ & $\mathrm{P}_{\mathrm{i}}$ & $\mathrm{S}_{\mathrm{i}}{ }^{(1)}$ & $\mathrm{S}_{\mathrm{i}}{ }^{(2)}$ & $\mathrm{Hom}_{\mathrm{i}}$ \\
\hline Max & 0.22 & & & & & & & & \\
\hline Min & 0.57 & -0.37 & & & & & & & \\
\hline $\mathrm{b}_{\mathrm{i}}$ & 0.26 & 0.79 & -0.56 & & & & & & \\
\hline $\mathrm{S}^{2} \mathrm{~d}_{\mathrm{i}}$ & -0.42 & 0.30 & -0.30 & 0.16 & & & & & \\
\hline $\mathrm{P}_{\mathrm{i}}$ & -0.96 & -0.12 & -0.56 & -0.18 & 0.64 & & & & \\
\hline $\mathrm{S}_{\mathrm{i}}{ }^{(1)}$ & -0.43 & 0.53 & -0.77 & 0.59 & 0.69 & 0.56 & & & \\
\hline $\mathrm{S}_{\mathrm{i}}{ }^{(2)}$ & -0.07 & 0.27 & -0.06 & 0.19 & 0.69 & 0.30 & 0.56 & & \\
\hline $\mathrm{Hom}_{\mathrm{i}}$ & 0.59 & -0.47 & 0.91 & -0.61 & -0.58 & -0.65 & -0.86 & -0.27 & \\
\hline $\mathrm{Sc}_{\mathrm{i}}$ & 0.61 & -0.47 & 0.98 & -0.55 & -0.40 & -0.62 & -0.81 & -0.11 & 0.94 \\
\hline
\end{tabular}

Based on data in Tables 4 and 5, it can be observed that statistical indices characterized the genotypes in different ways. Some parameters estimate the stability only, without considering yield level. Other indices related with the mean yield, with the maximum or minimum its limits.

\section{GGE biplot analysis}

The first two principal components of the GGE biplot explained $70.29 \%$ of genotype-environment interaction. Figure 1 shows the representativeness and discriminating ability of environments. The line that intersects the center of the biplot is the average environment axis (AEA). The average environment represented by the small circle at the end of the arrow. The dashed lines indicate the vectors of individual test environments. The length of the vector characterizes discriminating ability of an environment. The angle between the vector of environment and the AEA showes its representativeness. A test environment that has a smaller angle with AEA is more representative than other test environments. The environment of M16 was characterized by the greatest differentiating ability. The environment N16 was the most representative, whereas M15 and K18 were the least representative. The environments M15 and K18 were the most distant from each other. The environments M17, M18, and $\mathrm{K} 16$, as well as N17 and N18 were similar among themselves. 
GGE biplot "which-won-where" polygon view is effective tool to visualize the interaction patterns between genotypes and environments (Fig. 2). The polygon is formed by connecting the genotypes that are farthest away from the center of biplot, such that all other genotypes are contained within the polygon. A set of perpendicular to each side of the polygon lines divide the biplot into several sectors. In the sectors at the vertex of the polygon locates genotypes that have an advantage in a particular environment or in a set of environments (megaenvironment). In this case, the first mega-environment is formed by the environments M16, M17, M18, N16, and K16. The two breeding lines Nutans 4941 (G6) and Deficiens 5005 (G4) had advantage in it. The second megaenvironment was formed by the environments M15, N17, N18. The breeding line Nutans 4983 (G2) had higher yield in it. The breeding line Nutans 4855 (G8) was located on the straight line that connected the two above-mentioned megaenvironments. The breeding line Nutans 4890 (G3) was distinguished in the environment K17. In the environment K18 the standard variety Vzirets (G1) was the best. Thus, it can be seen that the first two mega-environments are formed by different ecological environments. This confirms that not only ecological, but also meteorological conditions of the years of the research significantly influenced on the yield performance of the genotypes.

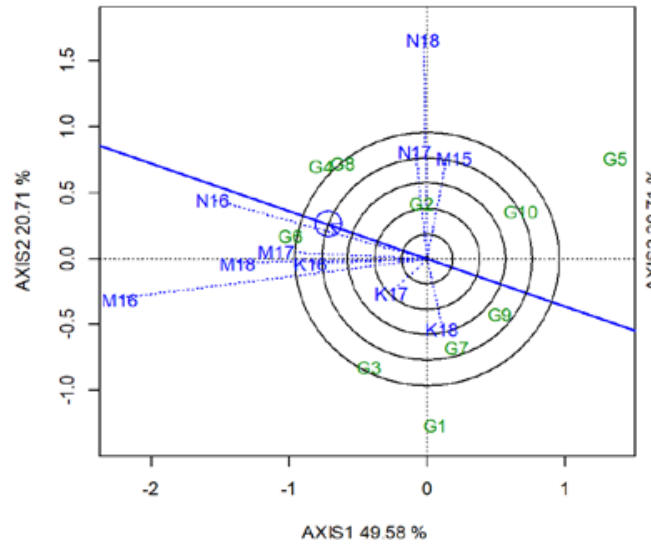

Figure 1. GGE biplot of discriminating ability and representativeness of test environments

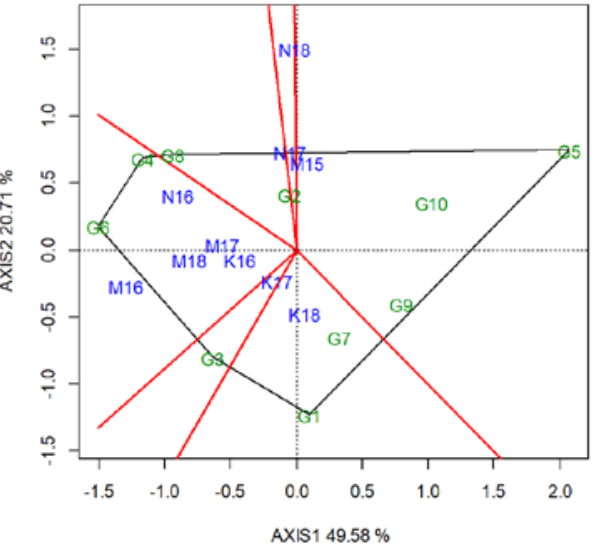

Figure 2. GGE biplot "which-wonwhere" polygon view for breeding lines and test environments

Figure 3 shows the average environment coordination of breeding lines in terms of mean yield and stability. The axis intersecting the center of the GGE biplot horizontally is the average environment abscissa (or AEA) for the environments. In the direction marked with arrow distinguished by a circle on the abscissa, the cultivars are ranked by mean yield. In the vertical plane, the average ordinate intersects the center of the GGE biplot. The intersection point represents the grand mean yield across environments. The displacement of genotypes along the ordinate axis from the abscissa (indicated by dash line) characterizes their variability with respect to the expected mean performance. The maximum yield 
was noted in the breeding line Nutans 4941 (G6), the minimum yield was in Nutans 5006 (G5). The breeding line Nutans 5006 (G5) was also the most variable. The breeding lines Deficiens 5005 (G4), Nutans 4855 (G8) and Nutans 4867 (G9) were stable. However, the breeding line Nutans 4867 (G9) had lower yield than the mean yield in trial and standard variety Vzirets (G1).

Figure 4 shows ranking the breeding lines relative to a hypothetical "ideal genotype” which conventionally is represented as the center of centric circles. By the combination of yield and stability, the line Deficiencs 5005 (G4) was significantly distinguished. The breeding line Nutans 4855 (G8) was close to an "ideal genotype" also. The breeding line Nutans 4941 (G6) was slightly shifted away from the center as a result of higher variability. The breeding lines Nutants 4983 (G2) and Nutans 4890 (G3) were inferior to the three mentioned, but exceeded the rest of the breeding lines and the standard variety Vzirets (G1).

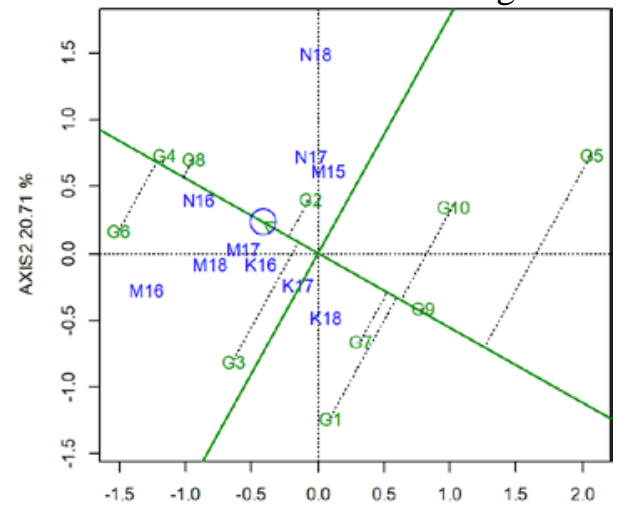

AXIS1 $49.58 \%$

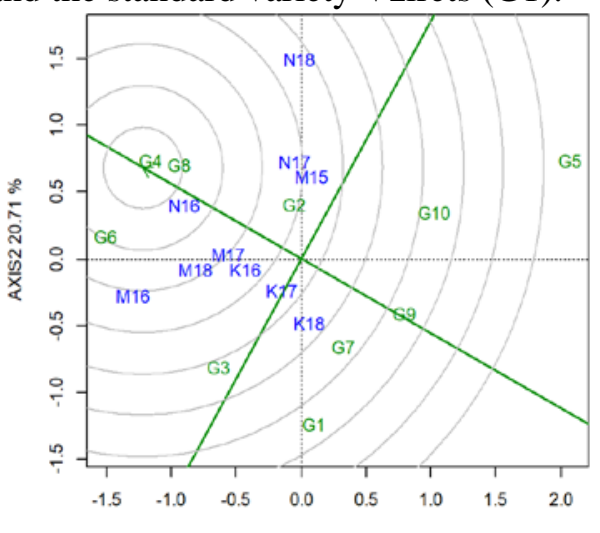

AXIS1 $49.58 \%$

Figure 3. GGE biplot average nvironment Figure 4. GGE biplot ranking spring coordination view of spring barley barley breeding lines relative to an breeding lines for mean yield against "ideal genotype" stability

Resulted from the research, the breeding lines Deficiens 5005, Nutans 4855, Nutans 4941 and Nutans 4890 have been submitted to the State Strain Testing of Ukraine as new varieties MIP Visnyk, MIP Ekspert, MIP Myroslav and MIP Vdiachnyi, respectively.

\section{CONCLUSIONS}

The high variability in yield of spring barley breeding lines has been established. It is caused by both different ecological conditions and meteorological conditions of the years of the research. The ANOVA revealed significant contributions from all three sources of variation: genotype, environment and genotype-environment interaction. The effect of environmental conditions was the highest $-90.42 \%$.

The applied statistical indices in different ways characterized the investigated spring barley breeding lines. Some indices estimated the stability 
only, without considering yield level $\left(\mathrm{S}^{2} \mathrm{~d}_{\mathrm{i}}, \mathrm{S}_{\mathrm{i}}{ }^{(2)}\right)$. Other indices were related (positive or negative) with the mean yield $\left(\mathrm{P}_{\mathrm{i}}\right)$, with the maximum $\left(\mathrm{b}_{\mathrm{i}}\right)$ or minimum $\left(\mathrm{S}_{\mathrm{i}}{ }^{(1)}, \mathrm{Hom}_{\mathrm{i}}, \mathrm{Sc}_{\mathrm{i}}\right)$ its limits. The GGE biplot model has provided indepth visual mega-environment analysis of multi-environment trial data.

The combination of statistical indices and graphic model was effective for comprehensive evaluation of the genotype-environment data from multienvironment trials. This approach allows identify the best of the best breeding lines at the final stage of breeding work.

The breeding lines Deficiens 5005, Nutans 4855, Nutans 4941 and Nutans 4890 have been submitted to the State Strain Testing of Ukraine as new varieties MIP Visnyk, MIP Ekspert, MIP Myroslav and MIP Vdiachnyi, respectively.

\section{REFERENCES}

Dimova D., Krasteva L., Panayotov N., Svetleva D., Dimitrova M., Georgieva T. 2012. Evaluation of the yield and the yield stability of perspective lines of barley. Agroznanje, 13(1): 55-60. https://doi.org/10.7251/AGREN1201055D

Eberhart S.A., Russel W.A. Stability parameters for comparing varieties. 1966. Crop Sci., 6(1): 36-40. https://doi.org/10.2135/cropsci1966.0011183X000600010011x

Frutos E., Galindo M.P., Leiva V. 2014. An interactive biplot implementation in $\mathrm{R}$ for modeling genotype-by-environment interaction. Stoch. Environ. Res. Risk Assess., 28(7): 1629-1641. https://doi.org/10.1007/s00477-013-0821$\mathrm{Z}$

Grausgruber H., Bointer H., Tumpold R., Ruckenbauer P., Fishbeck G. 2002. Genetic improvement of agronomic and qualitative traits of spring barley. Plant Breed., 121(5): 411-416. https://doi.org/10.1046/j.14390523.2002.756385.x

Hill J. 1975. Genotype-environment interaction - a challenge for plant breeding. J. Agricul. $\quad$ Sci., 85(3): https://doi.org/10.1017/S0021859600062365

Huehn M. 1990. Nonparametric measures of phenotypic stability. Part 1: Theory. Euphytica, 47 (3): 189-194. https://doi.org/10.1007/BF00024241

Khangildin, V.V., Litvinenko, N.A. 1981. Homeostaticity and adaptability of winter wheat varieties. Scient. Tech. Bull. PBGI, 39: 8-14.

Khanzadeh H., Vaezi B., Mohammadi R., Mehraban A., Hosseinpor T., Shahbazi K. 2018. Grain yield stability of barley genotypes in uniform regional yield trails in warm and semi warm dry land area. Ind. J. Agric. Res., 52(1): 1621. https://doi.org/10.18805/IJARe.A-290

Kiliç H., Kendal E., Aktas H. 2018. Evaluation of yield and some quality characters of winter barley (Hordeum vulgare L.) genotypes using biplot analysis. Agriculture \& $\quad$ Forestry, https://doi.org/10.17707/AgricultForest.64.3.09

Laidig F., Piepho H. P., Rentel D., Drobek, T., Meyer U. 2017. Breeding progress, genotypic and environmental variation and correlation of quality traits in malting barley in German official variety trials between 1983 and 2015. Theor. Appl. Genet., 130(11): 2411-2429. https://doi.org/10.1007/s00122-017-2967-4 
Lillemo M., Reitan L., Bjørnstad A. 2009. Increasing impact of plant breeding on barley yields in central Norway from 1946 to 2008. Plant Breed., 129(5): 484-490. https://doi.org/10.1111/j.1439-0523.2009.01710.x

Lin C.S., Binns M.R. 1988. A superiority measure of cultivar performance for cultivar $\mathrm{x}$ location data. Can. J. Plant Sci., 68(1): 193-198. https://doi.org/10.4141/cjps88-018

Macholdt J., Honermeier B. 2016. Impact of climate change on cultivar choice: adaptation strategies of farmers and advisors in German cereal production. Agronomy, 6: 40. https://doi.org/10.3390/agronomy6030040.

Malosetti M., Ribaut J.-M., van Eeuwijk F.A. 2013. The statistical analysis of multi-environment data: modeling genotype-by-environment interaction and its genetic basis. Front. Physiol., 4: 44. https://doi.org/10.3389/fphys.2013.00044

Psota V., Hartmann J., Sejkorova S., Louckova T., Vejrazka K. 2009. 50 Years of progress in quality of malting barley grown in the Czech Republic. J. Instit. Brew., 115(4), 279-291. https://doi,org/10.1002/j.20500416.2009.tb00382.x

Sabaghnia N., Mohammadi M., Karimizadeh R. 2013. Yield stability of performance in multi-environment trials of barley (Hordeum vulgare L.) genotypes. Acta Univ. Agric. Silvic. Mendelianae Brun., 61(3): 787-793. http://dx.doi.org/10.11118/actaun201361030787

Solonechnyi P., Kozachenko M., Vasko N., Gudzenko V., Ishenko V., Kozelets G., Usova N., Logvinenko Y., Vinyukov A. 2018. AMMI and GGE biplot analysis of yield performance of spring barley (Hordeum vulgare L.) varieties in multi environment trials. Agriculture \& Forestry, 64(1): 121132. https://doi.org/10.17707/AgricultForest.64.1.15

Vaezi B., Pour-Aboughadareh A., Mohammadi R., Armion M., Mehraban A., Hossein-Pour T., Dorii M. 2017. GGE biplot and AMMI analysis of barley yield performance in Iran. Cereal Res. Commun., 45(3): 500-511. https://doi.org/10.1556/0806.45.2017.019

Verma A., Singh J., Kumar V., Kharab A. S., Singh G. P. 2017. Non parametric analysis in multi environmental trials of feed barley genotypes. Int. J. Curr. Microbiol. $\quad$ App. $\quad$ Sci., $\quad 6(6): \quad 1201-1210$. https://doi.org/10.20546/ijcmas.2017.606.139

van Eeuwijk F.A., Bustos-Korts D.V., Malosetti M. 2016. What should students in plant breeding know about the statistical aspects of genotype $\times$ environment interactions? Crop Sci., 56(5): 2119-2140. https://doi.org/10.2135/cropsci2015.06.0375

Yan W., Tinker N.A. 2006. Biplot analysis of multi-environment trial data: principles and applications. Can. J. Plant Sci., 86(3): 623-645. https://doi.org/10.4141/P05-169

Yan W., Kang M.S., Ma B., Woods S., Cornelius P.L. 2007. GGE biplot vs. AMMI analysis of genotype-by-environment data. Crop Sci., 47(2): 643653. https://doi.org/10.2135/cropsci2006.06.0374 